\title{
Business Model Development Strategy on Property Industry: Case Study on PT CNI
}

\author{
Trevy Astri Dinna, Mukhamad Najib, and Mochammad Mukti Ali \\ School of Business, IPB University \\ Email: astridinna@yahoo.com
}

\begin{abstract}
PT CNI is a property developer company located in Cibubur. A high demand of residence leads many developer companies offer some types of housing in this area. PT CNI is currently experiencing a sales-declining, due to the high level of business competition and the sluggish national property market. Therefore, a new strategy formulation is needed that could be applied to re-increase company sales. This study aims to develop a company's strategy by describing and improving the business model of the company based on business model canvas (BMC), IE matrix, SWOT analysis, and blue ocean strategy approach. The data is collected by interviews, questionnaires, and literature studies. Informants were determined through a purposive sampling technique. From the results of the analysis, several strategies were formulated. Then the strategies were mapped back to the new BMC. The improvement shows that there are enhancements to some elements in the company's BMC.
\end{abstract}

Keywords:blue ocean strategy, business model canvas, property industry, strategy formulation, SWOT analysis.

\begin{abstract}
Abstrak: PT CNI merupakan salah satu perusahaan properti yang terletak di Cibubur. Saat ini perusahaan tengah mengalami penurunan penjualan yang disebabkan oleh semakin tingginya tingkat persaingan bisnis di kawasan tersebut dan pasar properti nasional yang memang sedang lesu. Oleh karena itu diperlukan formulasi strategi baru yang dapat diterapkan untuk kembali meningkatkan daya saing perusahaan. Penelitian ini bertujuan untuk menyusun strategi perusahaan dengan menggambarkan dan memperbaiki model bisnis yang dimiliki perusahaan melalui pendekatan business model canvas, analisis internal dan eksternal, matriks IE, analisis SWOT dan blue ocean strategy. Prosedur pengumpulan data yang digunakan pada penelitian ini adalah wawancara, kuisioner, dan studi pustaka. Narasumber dipilih menggunakan teknik purposif. Dari hasil analisis, dirumuskan beberapa strategi untuk perusahaan. Strategi-strategi yang dihasilkan kemudian dipetakan kembali dalam business model canvas perbaikan. Pada hasil perbaikan tersebut terdapat peningkatan terhadap beberapa elemen dalam business model canvas perusahaan.
\end{abstract}

Kata Kunci: analisis SWOT, blue ocean strategy, business model canvas, formulasi strategi, industri property.

\section{INTRODUCTION}

Every year, the population in DKI Jakarta has increased with the population growth rate reach 1,19\% in 2019 (BPS, 2020). The increasing number of inhabitants in an area 
causing a high demand for residence as well. It is because residence is still one of basic needs or primary needs, along with foods and clothing. A high demand of residence in Jakarta, has resulted the land prices in that area surged every year. This situation makes people choose to find alternative area for their residence in a buffer zone.

One of favorite buffer zone to live in is Cibubur. Beside its strategic location, only 30 minutes drive from DKI Jakarta, currently in the Cibubur area there are several infrastructure development projects. Some of development projects are the construction of Jakarta Outer Ring Road 2 (JORR 2) and the construction of the Light Rail Transit (LRT) transportation mode. The construction of infrastructure is a catalyst to increase industrial market growth in an area including the property industry.

A high demand of residence leads many developer companies offer some types of housing in this area. PT CNI is one of a property companies that located in Cibubur. This company started in 2017 and offers several products like landed house, lots, and house shop. Currently, the company is facing a decline in sales where the company sales in 2019 dropped by more than $20 \%$ compared to the previous year.

One of the factors that caused the decline of PT CNI is the number of other housing estates in the region that offer cheaper prices with almost the same market segment. This is considered a challenge for companies to continue to survive in the middle of an intense competition. Besides facing pressure from other competitors, the company must also face a difficult condition where the property industry is experiencing a decline in sales nationally. Based on a survey from Bank of Indonesia on Residential Property Price Index, the sales for residential property in 2019 is having a decreased growth from 13,39\% (yoy) to 1,19\% (yoy). The survey was also reported that high mortgage rates in 2019 were the main factor that caused the decline in residential property sales. Other factors causing sales to decline are licensing or bureaucratic factors in land development, a high proportion of advances in applying for mortgage loans in banks, and tax issues (BI, 2020).

In facing these unfavorable conditions, companies are required to think more creatively in creating innovations and new strategies so they can continue to survive in industrial competition. Strategy is a set of commitment and coordination of the activities built in maximizing competencies to achieve competitive advantage (Wheelen and Hunger 2012). Competitive advantage is created by using its resources and ability to achieve the cost structure of its lower endeavors, as well as its ability to differentiate the business or products of its competitors (Pearce and Robinson, 2004). As the first step in developing a strategy, the company needs to understand well the current situation of the company. The company needs to understand and identificate elements in their business model to be able to manage and make predictions about the business that they have (Trkman et al., 2015).

Based on the argument, it is necessary to perform a study to develop strategies in developing a right business model for this property company. The purpose of this research is to identify the business model that is currently run by the company, analyze internal and external factors that affect company performance, and develop the improved its business model.

\section{THEORETICAL REVIEW}

Business Model. The business model is a model that is used in doing business so that the company can generate revenue to maintain their existence (Turban, 2011). The approach 
using the business model approach can be an effective tool for assessing business potential before developing a business plan. This methodology is broadly applicable for new companies, existing companies, as well as non-profit companies and organisations (Gavrilova et al., 2014). According to (Fielt, 2013), in an attempt to capture changes in dynamic business conditions, business modeling uses dimensions that discuss customer, value proportion, organizational architecture and economy. The value proposition can be seen as a central dimension. Whereas organizational architecture can include company level and corporate network level. On the other hand, the economic dimension includes nonfinancial considerations. These dimensions will be based on questions about who, what, why, and how to create and capture value for customers.

Besides the many advantages that are offered by the business model in capturing new things in market development, this analysis tool also has some weaknesses. According to (Ghezzi, 2014), those weaknesses include: the inability to explain a) the industrial structural appeal, b) contextual chances and threats, c) the company's relative position in the market, d) costs spent by the company and the value of the profit, e) strengths and weaknesses of competitors, and f) alternative strategies from the company. Hence, the use of business models needs to be equipped with other analytical tools like SWOT analysis so that they can get maximum results.

Business Model Canvas. (Osterwalder and Pigneur, 2012) explained that BMC illustrates the rationale on how organization creates, delivers, and capture value. BMC also identifies areas of business innovation. Its application value means that it can be used in the planning of business plan regard to the necessary information, content, contained analysis related to marketing, operational, financial or organizational and management plan (Toraski et al., 2017). BMC can be a more flexible tool as well as an effective and adaptive budgeting, so that BMC makes it possible to detect ineffective and excessive costs in creating value for customers (Dudin et al,. 2015). BMC is used as an instrument that provides a clear view of what companies need to achieve and focuses on the most important strategic elements and will have the greatest impact on business (Amanulla et al., 2015). BMC has an advantage in business model analysis since it is able to simply and thoroughly describe the current condition of a company based on the customer segment, the value offered, the stream of value offered, relationship with customers, revenue stream, vital assets, partners, and cost structures that are owned (Rainaldo et al., 2017). BMC is a very good tool for the company to plan and build the new solution and to improve the current business (Abiyyu et al., 2020)

An improvement in the company's business model is needed to improve and build the company's internal organisation (Casadesus and Ricart, 2010). Innovative business models must be able to fit internal capabilities or adapt to external changes, such as technological developments (Chesbrough, 2002) or change customer values (Mc Grath, 2010). (Eskelinan et al., 2017) stated that innovation proved to be an important factor and a useful method in business model development accompanied by good analytical and development tools.

Blue Ocean Strategy. Blue ocean strategy can be used as a strategy tool used in the creation of new BMC (Abiyyu et al., 2020). According to (Shafiq et al., 2017) Blue Ocean Strategy is a concept that emphasizes on value innovation. The value innovation was not intended so that they can collide with other organizations in order to compete for market share, but to explore new markets and innovate values for customers and the organization itself (Kim and 
Mauborgne, 2005). According to (Kim and Mauborgne, 2005) there are four actions framework in developing value innovations for customers and organizations, which are eliminating, reducing, raising, and creating.

\section{METHODOLOGY}

The research was conducted at PT CNI located in Cibubur area, Bekasi City, from January to April 2020. This research was done using a descriptive analysis method in the form of case studies. The type of collected data consisted of primary and secondary data. Primary data were obtained from questionnaire and in-depth interview with informants. While secondary data were obtained by accessing information and documents held by companies and related institutions as well as other data sources such as books, theses, journals and relevant scientific publications. Informants were determined through a purposive sampling technique. The selected informants were those who were considered to have a deep understanding of the overall condition of the company, such as the General Manager, Marketing Manager and Project Manager of PT CNI.

The stages carried out in this study were begun by mapping the business model carried out by PT CNI by analyzing the company's environment and business activities using nine elements in the BMC. There are nine components in BMC which are customer segments, channels, value proposition, customer relationship, key partnership, revenue streams, key activities, key resource and cost structure (Osterwalder and Pigneur, 2012). Next is the identification of the company's internal and external factors. Each of these factors was then weighted and ranked using Internal Factor Evaluation (IFE) and External Factor Evaluation (EFE) matrices. Based on the total score obtained from the IFE and EFE matrices, the next step was to determine the company's position in the IE matrix. Then, SWOT analysis was performed to formulate alternative strategies. The results of the strategy were then combined with a four-step framework of the blue ocean strategy. The combination of these strategies was further mapped in the preparation of the new company's BMC.

\section{THE RESULTS OF STATISTICAL TESTS}

The Identification of PT CNI Current Business Models. The results of the PT CNI business model identification were obtained based on in-depth interviews conducted with internal company management. The results of the identification of PT CNI business model are in Table 1. (1) Customer Segments: PT CNI offers a luxurious housing with modern and complete facilities. The price of the product offered is considered high which is why the targeted customer segmentation are those who get the upper middle class. The company also provides a variety of products for investors and end customers. The majority of customers come from the areas around its project like East Jakarta, South Jakarta, Bekasi and Bogor. (2) Value Proposition: PT CNI is a subsidiary of Ciputra Group, one of the biggest property developer company in Indonesia, which has a positive image in the community. PT CNI was the first to offer the concept of housing within the Central Business District (CBD) area in Cibubur so that the increase in land prices was quite significant here. The increase of land prices in PT CNI project in Desember 2019 reached more than 24\% from the previous year.This residential area also has complete facilities with the concept of transit oriented development (TOD) as well as a good security system. (3) Channel: PT CNI uses direct as 
well as indirect methods in the delivery of its products. When it comes to direct methods, it was carried out by participating in various exhibitions, open houses, and holding some contest. While the indirect way of delivering the products was done by using print and social media. Print media that were being used including the installation of billboards, banners and distribution of brochures, while on social media they used google ads, websites, instagram, facebook and youtube. (4) Customer Relationship: PT CNI builds customer relationships through customer gathering, giving discounts and promos, as well as after-sales service by receiving customer complaints, maintaining cleanliness and security of the area, and providing product guarantees. (5) Revenue Stream: PT CNI biggest revenue was obtained from product sales, such as houses, shop houses and lots. In addition to product sales, the company also received other income from environmental and park management fees (IPLK) retribution, water usage costs, house renovation costs, building construction costs, unit cancellation costs, refusal costs for filing mortgages and also penalty costs. The company also provides various alternative ways to pay to increase convenience for customers. (6) Key Activity: As a property developer, PT CNI key activities consist of area planning, land acquisition, design of product details, calculation of construction costs, marketing, construction work, and after sales services. (7) Key Resources: Resources owned by PT CNI including financial resources, human resources, physical resources and technological resources. Financial resources are in the form of initial capital from shareholders' deposits. Human resources consist of 49 employees who are spread into several divisions like marketing division, engineering division, financial division, Human Capital Management (HCM) division, licensing division and estate management division. Physical resources cover a land area of $60 \mathrm{ha}$, as well as office buildings and facilities that consist of marketing offices, after sales service offices, and project offices. While PT CNI technology resources are in the form of systems and applications that can be connected directly between divisions and headquarters. (8) Key Partnership: As a developer, PT CNI is a member of the Real Estate Indonesia (REI). PT CNI cooperates with various parties such as community leaders, the government, consultants, suppliers and contractors. In addition, PT CNI also cooperates with notaries, banks, brokerage agencies and advertising companies. (9) Cost Structure: Company expenses are divided into several items. The biggest financing is for construction activities by $54 \%$, then followed by infrastructure development costs by $21 \%, 18 \%$ for the operating costs along with licensing fees and taxes by $6 \%$.

Table 1. PT CNI Current Business Model Canvas

\begin{tabular}{|c|c|c|c|c|}
\hline $\begin{array}{ll} & \text { Key Partners } \\
\text { - } & \text { Member of REI } \\
\text { - } & \text { Notary } \\
\text { - } & \text { The government } \\
\text { - } & \text { Public figures } \\
\text { - } & \text { Contractors } \\
\text { - } & \text { Consultants } \\
\text { - } & \text { Suppliers } \\
\text { - } & \text { Banks }\end{array}$ & $\begin{array}{l}\text { Key Activities } \\
\text { - Regional Planning } \\
\text { - Land acquisition } \\
\text { and legality } \\
\text { management } \\
\text { - Product design } \\
\text { - } \text { Cost calculation } \\
\text { - Marketing } \\
\text { - Construction work } \\
\text { - } \text { After sales service }\end{array}$ & $\begin{array}{l}\text { Value Proposition } \\
\text { - The first housing } \\
\text { concept in the } \\
\text { CBD area in } \\
\text { Cibubur } \\
\text { - Significant } \\
\text { increase in land } \\
\text { prices } \\
\text { - TOD concept } \\
\text { - Complete }\end{array}$ & $\begin{array}{l}\text { Customer } \\
\text { Relationship } \\
\text { - } \text { Customer } \\
\text { gathering } \\
\text { - Discounts, } \\
\text { cashback, and } \\
\text { direct prizes } \\
\text { - After sale service }\end{array}$ & $\begin{array}{l}\text { Customer Segment } \\
\text { - Upper-middle } \\
\text { class community } \\
\text { - Investor } \\
\text { - Final customer } \\
\text { - Domicile in East } \\
\text { Jakarta, South } \\
\text { Jakarta, Bekasi, } \\
\text { and Bogor } \\
\text { - Millennial } \\
\text { consumers }\end{array}$ \\
\hline
\end{tabular}




\begin{tabular}{|c|c|c|c|c|}
\hline $\begin{array}{l}\text { - Advertising } \\
\text { companies } \\
\text { - Newspapers and } \\
\text { magazines } \\
\text { - } \text { Brokerage agents } \\
\text { Outsource service } \\
\text { provider }\end{array}$ & $\begin{array}{l}\text { Key Resources } \\
\text { - Financial resources } \\
\text { - Human Resources } \\
\text { - Physical resources } \\
\text { - Technological } \\
\text { resources }\end{array}$ & $\begin{array}{l}\text { facilities } \\
\text { - one gate system } \\
\text { - The positive } \\
\text { image of the } \\
\text { company in } \\
\text { public } \\
\text { - Superior material } \\
\text { specifications }\end{array}$ & $\begin{array}{l}\quad \text { Channels } \\
\text { Direct: } \\
\text { - Exhibition } \\
\text { - Open house } \\
\text { - Contest } \\
\text { Indirect: } \\
\text { - Print media } \\
\text { - Online media }\end{array}$ & \\
\hline \multicolumn{3}{|l|}{$\begin{array}{l}\text { - } \text { Costs for building } \\
\text { - Infrastructure deve } \\
\text { - Permit cost } \\
\text { - Tax costs } \\
\text { - Operational costs }\end{array}$} & \multicolumn{2}{|c|}{ 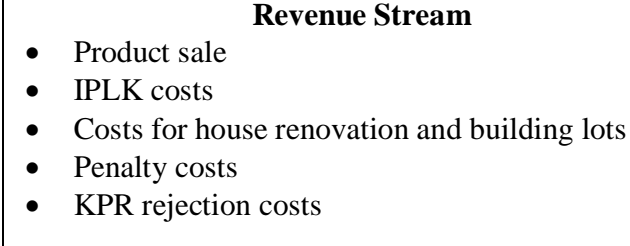 } \\
\hline
\end{tabular}

The Evaluation of Internal and External Factors of the Company. After identifying the company's existing condition, determining the environmental factors that affect company performance is the next thing to do. The factor selection were obtained based on in-depth interview conducted with internal company management. Those factors are then evaluated by assigning the weight and rating on IFE and EFE matrices. The determination of weight and rating of each factor is done by questionnaire filled. The analysis of the internal environment includes evaluating the strengths and weaknesses of the company. Weaknesses must be continuously improved so that they can be transformed into one of the strengths of the organization. In fact, if it is possible, it can be improved to become distinctive competencies because if a company has distinctive competencies it can make the organization to become stronger (Darmawan et al., 2015). Based on the evaluation, the total IFE score was 2,63 (Table 2) and the total EFE score was 2,73 (Table 2).

Table 2. PT CNI IFE Matrix

\begin{tabular}{|c|c|c|c|c|}
\hline No. & Internal Factor & Weight & Rating & Score \\
\hline & Strength & & & \\
\hline 1 & The positive image of the company in public & 0,12 & 4 & 0,48 \\
\hline 2 & A lot of variety of products & 0,12 & 3 & 0,36 \\
\hline 3 & Significant increase in land prices & 0,14 & 4 & 0,56 \\
\hline \multirow[t]{2}{*}{4} & Various alternative ways to pay & 0,14 & 3 & 0,42 \\
\hline & Weakness & & & \\
\hline 1 & The CBD area has not yet been developed & 0,12 & 2 & 0,24 \\
\hline 2 & $\begin{array}{l}\text { The lack of closeness building with } \\
\text { customers }\end{array}$ & 0,08 & 2 & 0,16 \\
\hline 3 & $\begin{array}{l}\text { The lack of skills that the marketers have at } \\
\text { delivering products }\end{array}$ & 0,14 & 2 & 0,28 \\
\hline 4 & A tendency to give higher price & 0,13 & 1 & 0,13 \\
\hline & Total IFE Score & & & 2,63 \\
\hline
\end{tabular}

EFE matrix contains a summary of the results of external audits consisting of the main opportunities and threats of the company (Capps and Glissmeyer, 2012). Based on the evaluations, the total EFE score was 2,73 (Table 3). 
Table 3. PT CNI EFE Matrix

\begin{tabular}{|c|c|c|c|c|}
\hline No. & External Factor & Weight & Rating & Score \\
\hline & Opportunity & & & \\
\hline 1 & $\begin{array}{l}\text { Infrastructure development carried out by the } \\
\text { government }\end{array}$ & 0,17 & 3 & 0,50 \\
\hline 2 & $\begin{array}{l}\text { An increasing number of millennial } \\
\text { customers }\end{array}$ & 0,13 & 3 & 0,38 \\
\hline \multirow[t]{2}{*}{3} & Technology and social media development & 0,19 & 4 & 0,78 \\
\hline & Threat & & & \\
\hline 1 & Decreasing of public purchasing power & 0,18 & 2 & 0,37 \\
\hline 2 & Competitors that offer cheaper price & 0,19 & 3 & 0,57 \\
\hline 3 & Cancellation of purchases by customers & 0,14 & 1 & 0,14 \\
\hline & Total EFE Score & & & 2,73 \\
\hline
\end{tabular}

IE Matrix. Mapping was the next thing to do towards the results of the evaluation of internal factors (IFE) and external (EFE) using the internal-external (IE) matrix. (Bobillo et al., 2010) stated that the IE matrix can explain the influence of the external and internal environment on company performance. The IE matrix has nine types of cells that show a combination of the total weighted values of the IFE and EFE matrices. According to (David, 2013) the nine cells can be divided into three groups of main strategies that have different strategy implications. The IE matrix is based on two key dimensions: the total IFE score on the $\mathrm{x}$-axis and the total EFE score on the y-axis. The total value of IFE obtained was included in the medium internal position category of 2,63 and the total value of EFE was also included in the category of average external position with a value of 2,73 (Figure 1).

Based on the results of the evaluation of IFE and EFE, it was found that the company classified into cell V (hold and maintain). According to (David, 2013) the strategies that can be applied in this position are product development and market penetration. Product development strategy aim to increase sales by increasing the value of existing products or services while market penetration strategy aim to increasing market share through wider marketing efforts.

Figure 1. PT CNI IE Matrix

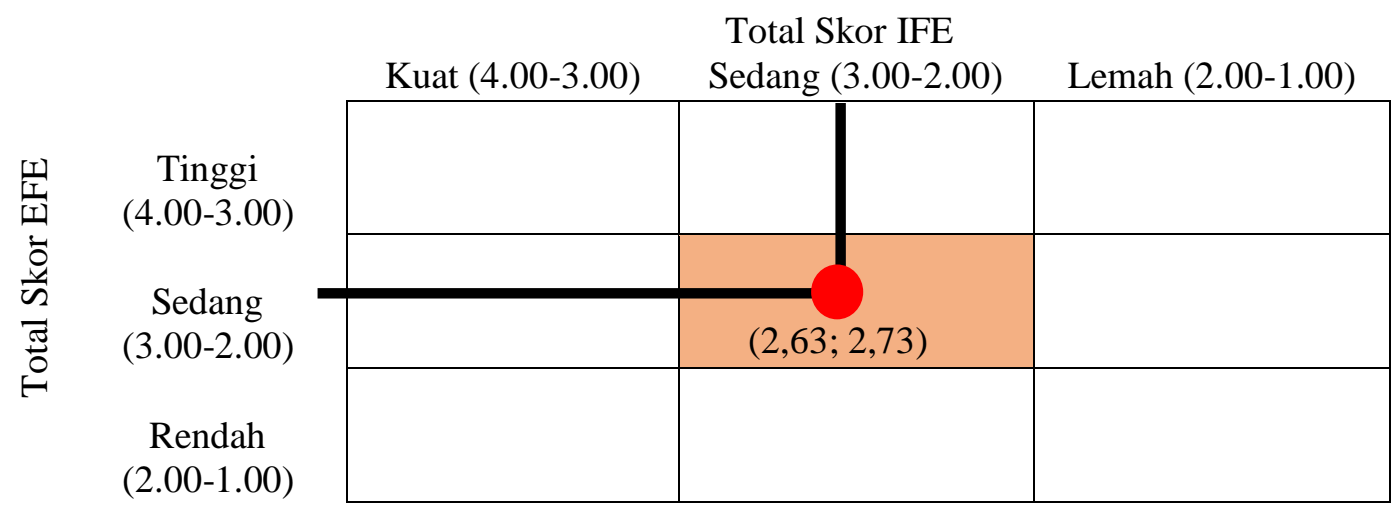


SWOT Analysis. As stated by (Moser, 2006), one of a series of effective analytical tools for designing strategies is to use SWOT analysis. The function of a SWOT analysis is to gain information of a situation analysis and separate it from internal issues (strengths and weaknesses) and external issues subject matters (opportunities and threats) (Ferrel and Harline 2005).

According to (David, 2013) the formulation of the SWOT strategy is carried out through a SWOT matrix which produces four alternative sets of strategies consisting of SO, WO, ST and WT strategies. SO strategy is kind of strategy which use all strength to seize the maximum opportunity, WO strategy is kind of strategy which take advantage of the opportunity to minimize its weakness, ST strategy is kind of strategy which use all strength to overcome the threats and WT strategy is kind of strategy which minimize weaknesses by avoiding threats. The results of the strategy formluation are shown on Table 4 .

Table 4. PT CNI SWOT Matrix

\begin{tabular}{|c|c|c|}
\hline External Factors & $\begin{array}{l}\text { Strength } \\
\text { 1. The positive image of the } \\
\text { company in public } \\
\text { 2. A lot of variety of } \\
\text { products } \\
\text { 3. Significant increase in } \\
\text { land prices } \\
\text { 4. Many alternative ways to } \\
\text { pay }\end{array}$ & $\begin{array}{l}\text { Weakness } \\
\text { 1. The CBD area has not yet } \\
\text { been developed } \\
\text { 2. The lack of closeness } \\
\text { building with customers } \\
\text { 3. The lack of skills that the } \\
\text { marketers have at delivering } \\
\text { products } \\
\text { 4. A tendency to give higher } \\
\text { price }\end{array}$ \\
\hline $\begin{array}{l}\text { Opportunity } \\
\text { 1. } \begin{array}{l}\text { Infrastructure } \\
\text { development carried out } \\
\text { by the government }\end{array} \\
\text { 2. An increasing number of } \\
\text { millennial customers } \\
\text { 3. Technology and social } \\
\text { media development }\end{array}$ & \begin{tabular}{l}
\multicolumn{1}{c}{ SO Strategy } \\
1. Provide edu-promotion to \\
the public about the \\
benefits of investment \\
$(\mathrm{S} 3, \mathrm{~S} 4, \mathrm{O} 1, \mathrm{O} 2)$, \\
2. Develop a concept of \\
environmentally friendly \\
buildings ( $\mathrm{S} 4, \mathrm{O} 2, \mathrm{O} 3)$ \\
3. To invent a promotional \\
program specially for \\
millenials (W2, W4, O2)
\end{tabular} & \begin{tabular}{l}
\multicolumn{1}{c}{ WO Strategy } \\
1. To create products with \\
smart home technology (W4, \\
O2, O3) \\
2. To develop home care \\
application, (W3, W4, O2, \\
O3, O4) \\
3. To provide incentives for \\
customers who are able to \\
sell products $(\mathrm{O} 3, \mathrm{~W} 3)$
\end{tabular} \\
\hline $\begin{array}{l}\text { Threat } \\
\text { 1. Public purchasing power } \\
\text { is decreasing } \\
\text { 2. Competitors that offer } \\
\text { cheaper price } \\
\text { 3. Cancellation of } \\
\text { purchases by customers }\end{array}$ & $\begin{array}{l}\quad \text { ST Strategy } \\
\text { 1. To build partnerships } \\
\text { with other business units } \\
\text { to create promotional } \\
\text { programs }(\mathrm{S} 1, \mathrm{~T} 1, \mathrm{~T} 2)\end{array}$ & $\begin{array}{ll}\quad \text { WT Strategy } \\
\text { 1. To start building CBD area } \\
\text { (W1, W4, T2, T3) } \\
\text { 2. Recruit some experienced } \\
\text { marketers (W3, T2, T3) } \\
\text { 3. } \begin{array}{l}\text { Improve personal services to } \\
\text { customers (W1, W2, T3) }\end{array}\end{array}$ \\
\hline
\end{tabular}

Based on the Table 3, herewith the explanations for each strategy: 
SO Strategies. (1) Providing some edu-promotions to the public regarding the benefits of investment. Edu-promotion is a product marketing activity by giving some education to potential customers (Ariendi et al., 2015). Besides aiming to communicate the products owned by the company, the implementation of edu-promotion also aims to increase public awareness about the benefits of investment. Such information can be conveyed with several interactive approaches like conducting talk shows or seminars by inviting economists, conducting advertisements on the radio, and making short video content for social media. Applying the concept of environmentally friendly buildings. (2) Global climate change is now increasingly gaining more attention from various groups of people. Most industries are currently creating products that are environmentally friendly, including the property industry. The concept of environmentally friendly housing or green property is emphasizing the efficiency in the use of water, energy and building materials (Erdiono, 2009). The application of green property can be done by creating building designs that can optimize air circulation and natural lighting so that residents do not have to use air conditioning and lighting too often. While in terms of material it can be done by using water-based paint, using aluminum foil in the framework of the roof so that it can reduce room temperature and the use of using grass blocks in the carport to increase water absorption to the ground. Apart from that, housing can also start to use solar cells. Solar cell is a technology which able to convert sunlight into electrical energy. The advantages of using solar cell on the roof of a house are helping to preserve the environment by using renewable energy sources, and not producing residue or exhaust gas so it does not pollute the environment. In addition, it can reduce household electricity bills as well. (3) Creating special millennial promotion programs. Currently, the whole industry is in the middle of launching various programs to gain the attention of potential millennial customers as the biggest customer segment. Millennial generation reaches $33.75 \%$ of Indonesia's population (KEMENPPPA, 2018). As one of the actors in the property industry, PT CNI also needs to create special programs such as giving special millennial discounts, special millennial DP promos, as well as granting payment methods like longer terms for repayment.

WO Strategies. (1) Creating products with smart home technology. Smart home is a concept that applies technology to a building which allows existing devices and systems to be connected to one another. Smart home technology can improve the safety and comfort for customers, because with this technology the entrance can only be accessed by using a fingerprint or password that has been set by the customer. In addition, customers can control their household electronic appliances such as lights, air conditioners, microwave and TV through remote control to reduce electrical waste when customers forget to switch off the equipment. (2) Developing home care applications. After-sales service needs more attention because customer satisfaction is a company priority. Customers who are satisfied with the products will convey this to their relatives so that it can be an effective promotion by word of mouth. Also, a satisfied customer often will make repeat order. One way to improve customer comfort and satisfaction is to develop a special application for residents or home care applications. The application aims so the residents can easily access services provided by the developer. The development of this application is a part of an innovation in the world of property in the era of industry 4.0, where the whole community demands everything that is fast and practical. With this application, customers can find out the progress of their house construction without having to come to the location. Customers can also find out 
information about the payment of the environmental management fees retribution and water usage costs every month. In addition, customers can also submit complaints and permits related to home renovation through the application without having to come to the after-sales service office. This application development will give positive impact on the company image as a whole. The development of this application proves that the company prioritizes the comfort and safety of its customers. (3) Providing incentives for customers. Word of mouth promotion or using reference from the closest person is one way to promote the product effectively. Companies can provide incentives for customers who succeed in helping the company's sales such as giving certain discounts in their next purchase for the customer, free payment of environmental and park management fees retribution for a certain period of time, or direct gift giving.

ST Strategy. Collaborating with other Ciputra business units to create promotional programs. As a subsidiary of Ciputra Group, PT CNI can establish cooperation with other Ciputra business units in improving services for customers. Ciputra Group also has malls and hotels in the Cibubur area. PT CNI can collaborate in providing shopping vouchers or overnight vouchers for customers with a certain minimum purchase or at certain moments such as when a customer is having a birthday or during the turn-key.

WT Strategies. (1) To start building CBD area. CBD area is the company's advantage that will distinguish itself with its competitors. However, the CBD construction that has not been carried out until now has caused the set price to be considered too expensive. For this reason, it is necessary to start building the CBD areas so that people are more confident in the products that they are going to buy. In addition, the construction of the CBD will also attract crowds so that more people will be aware of the development of the PT CNI project and shop houses that are starting to open their businesses will also be increasingly crowded. (2) To recruit some experienced marketers. Companies need to evaluate the performance of their sales force because they are unable to meet sales targets. Besides conducting training to continuously improve employee capabilities, the company is also expected to recruit more experienced marketing personnel. That is because training requires a long time to form the character of a strong and skilled marketing staff in delivering their products. Companies can recruit marketing personnel from competing companies or broker agents who are considered experienced, especially in the property sector. Experienced marketers are usually capable of approaching prospective customers according to their needs and characteristics so that they can establish closeness with old customers to form customer loyalty. (3) Improving personal services to customers. Establishing relationships with costomers can be done by creating personal service programs. Some programs that can be carried out include giving greeting cards and souvenirs at customers' precious moments such as when a customer is having a birthday or when a customer is handing over the house, inviting the customer to lay the first foundation stone, and routinely conducting a customer gathering. For customers, the greetings at these moments will give the impression that the company has given a personal touch that will create a positive impression in the future.

SWOT Strategies on Blue Ocean Strategy Perspective. Modeling the strategies in the blue ocean strategy perspective was done after obtaining a number of strategies from the results of the SWOT analysis. This perspective used a four action framework on the blue 
ocean strategy including creating, eliminating, improving and reducing. The relationship between the SWOT strategy and the blue ocean strategy perspective is shown in Table 5.

Table 5. The correlation of SWOT strategies in the blue ocean strategy perspective

\begin{tabular}{|c|c|c|c|c|}
\hline SWOT Strategies & Creating & Eliminating & Improving & Reducing \\
\hline $\begin{array}{l}\text { SO1: Provide edu- } \\
\text { promotion to the } \\
\text { public }\end{array}$ & $\begin{array}{l}\text { New marketing } \\
\text { technique }\end{array}$ & & $\begin{array}{l}\text { - Customer interest } \\
\text { - Promotion costs }\end{array}$ & \\
\hline $\begin{array}{l}\text { SO2: To apply a } \\
\text { concept of } \\
\text { environmentally } \\
\text { friendly buildings }\end{array}$ & & & $\begin{array}{l}\text { - Company's image } \\
\text { - Value-added } \\
\text { products } \\
\text { - Customer interest }\end{array}$ & $\begin{array}{l}\text { Materials that are } \\
\text { not } \\
\text { environmentally } \\
\text { friendly }\end{array}$ \\
\hline $\begin{array}{l}\text { SO3: To create a } \\
\text { promotional } \\
\text { program specially } \\
\text { for millenials }\end{array}$ & & & $\begin{array}{l}\text { - The interests of } \\
\text { millennial customers } \\
\text { - Promotions through } \\
\text { online media }\end{array}$ & $\begin{array}{l}\text { Promotion } \\
\text { through print } \\
\text { media such as } \\
\text { banners or flyers }\end{array}$ \\
\hline $\begin{array}{l}\text { WO1: To create } \\
\text { products with smart } \\
\text { home technology }\end{array}$ & New technology & & $\begin{array}{l}\text { - Company's image } \\
\text { - Value-added } \\
\text { products } \\
\text { - Customer interest } \\
\text { - Construction costs }\end{array}$ & $\begin{array}{l}\text { Electricity } \\
\text { consumption }\end{array}$ \\
\hline $\begin{array}{l}\text { WO2: To develop } \\
\text { an application for } \\
\text { public }\end{array}$ & New technology & $\begin{array}{l}\text { The papers } \\
\text { used for } \\
\text { printing bills }\end{array}$ & $\begin{array}{l}\text { - Value-added } \\
\text { products } \\
\text { - The relationship with } \\
\text { the customers } \\
\text { - Investment cost }\end{array}$ & $\begin{array}{l}\text { Time needed for } \\
\text { handling } \\
\text { complaints }\end{array}$ \\
\hline $\begin{array}{l}\text { WO3: to provide } \\
\text { incentives for } \\
\text { customers }\end{array}$ & New channel & & $\begin{array}{l}\text { - The relationship with } \\
\text { the customers } \\
\text { - Market reach }\end{array}$ & \\
\hline $\begin{array}{l}\text { ST1:Building } \\
\text { partnerships with } \\
\text { other business units } \\
\text { to create } \\
\text { promotional } \\
\text { programs }\end{array}$ & $\begin{array}{l}\text { More varied } \\
\text { promotional } \\
\text { programs }\end{array}$ & & $\begin{array}{l}\text { - Partnership } \\
\text { relationship } \\
\text { - Customer interest } \\
\text { - The relationship with } \\
\text { the customers }\end{array}$ & \\
\hline $\begin{array}{l}\text { WT1:To start } \\
\text { building CBD area }\end{array}$ & $\begin{array}{l}\text { A new and } \\
\text { modern business } \\
\text { district }\end{array}$ & & $\begin{array}{l}\text { - Customer interest } \\
\text { - Investment Value } \\
\text { - Infrastructure } \\
\text { development costs }\end{array}$ & \\
\hline $\begin{array}{l}\text { WT2: Recruit some } \\
\text { experienced } \\
\text { marketers }\end{array}$ & & & $\begin{array}{l}\text { - Loyalty and } \\
\text { customer interest } \\
\text { - Payroll costs }\end{array}$ & $\begin{array}{l}\text { Training time and } \\
\text { training costs }\end{array}$ \\
\hline $\begin{array}{l}\text { WT3: Improve } \\
\text { personal services to } \\
\text { customers }\end{array}$ & $\begin{array}{l}\text { New marketing } \\
\text { technique }\end{array}$ & & - Customer loyalty & \\
\hline
\end{tabular}


The Improvement of PT CNI Business Model. After modeling the SWOT strategy in the blue ocean strategy perspective, the next step is to make improvements to the company's business model. The improvement of the business model is very important for the success of the company which lets the company be able to adapt to changes in the market and business environment that are increasingly competitive (Amin et al., 2018). This time the need to restructure and redesign business models, products and services towards sustainability is a strategic problem of corporate management globally (Maasen, 2018).

In the BMC improvements, there are several points that are maintained and also several other points that are created, improved or reduced from the BMC that previously correspond with the strategies that have been formulated. The strategic mapping has a direct and indirect influence towards the elements in the new BMC. Direct changes are those that occur directly on the elements concerned, while indirect changes are changes that occur due to the influence of elements that shift the implementation of the resulting strategy. The BMC improvement of PT CNI is shown in Table 6.

Table 6. PT CNI Improved Business Model Canvas

\begin{tabular}{|c|c|c|c|c|}
\hline \multirow{2}{*}{$\begin{array}{ll} & \text { Key Partners } \\
\text { - } & \text { Member of REI } \\
\text { - } & \text { Notary } \\
\text { - } & \text { The government } \\
\text { of Bekasi city } \\
\text { - } & \text { Public figures } \\
\text { - } & \text { Contractors } \\
\text { - } & \text { Consultants } \\
\text { - } & \text { Suppliers } \\
\text { - } & \text { Banks } \\
\text { - } & \text { Advertising } \\
& \text { companies } \\
\text { - } & \text { Newspapers and } \\
& \text { magazines } \\
\text { - } & \text { Brokerage agents } \\
\text { - } & \text { Outsource service } \\
\text { provider } \\
\text { - } \text { other business } \\
\text { units } \\
\text { - } \text { Consumers as } \\
\text { sales partners }\end{array}$} & $\begin{array}{l}\text { Key Activities } \\
\text { - Regional } \\
\text { Planning } \\
\text { - Land acquisition } \\
\text { and legality } \\
\text { management } \\
\text { - Product design } \\
\text { - Cost calculation } \\
\text { - Marketing } \\
\text { - Construction } \\
\text { - } \text { Aork } \\
\text { - } \text { sfter sales } \\
\text { service }\end{array}$ & \multirow{2}{*}{$\begin{array}{l}\text { Value Proposition } \\
\text { - The first housing } \\
\text { concept in the CBD } \\
\text { area in Cibubur } \\
\text { - Significant increase } \\
\text { in land prices } \\
\text { - TOD concept } \\
\text { - Complete facilities } \\
\text { - one gate system } \\
\text { - The positive image } \\
\text { of the company in } \\
\text { public } \\
\text { - Superior material } \\
\text { specifications } \\
\text { - Eco-friendly } \\
\text { building } \\
\text { - smart home system } \\
\text { - Home care } \\
\text { application }\end{array}$} & $\begin{array}{l}\text { Customer } \\
\text { Relationship } \\
\text { - } \text { Customer } \\
\text { gathering } \\
\text { - Discounts, } \\
\text { cashback, and } \\
\text { direct prizes } \\
\text { - After sale service } \\
\text { - } \text { Personal service }\end{array}$ & \multirow[t]{2}{*}{$\begin{array}{l}\text { Customer Segment } \\
\text { - Upper-middle } \\
\text { class community } \\
\text { - Investor } \\
\text { - Final customer } \\
\text { - Domicile in East } \\
\text { Jakarta, South } \\
\text { Jakarta, Bekasi, } \\
\text { and Bogor } \\
\text { - Millennial } \\
\text { consumers }\end{array}$} \\
\hline & $\begin{array}{l}\text { Key Resources } \\
\text { - Financial } \\
\text { resources } \\
\text { - Human Resources } \\
\text { - Physical } \\
\text { resources } \\
\text { - Technological } \\
\text { resources }\end{array}$ & & $\begin{array}{l}\text { Channels } \\
\text { Direct: } \\
\text { - Exhibition } \\
\text { - Open house } \\
\text { - Contest } \\
\text { - Talk show and } \\
\text { seminar } \\
\text { Indirect: } \\
\text { - Print media } \\
\text { - Online media }\end{array}$ & \\
\hline \multicolumn{3}{|c|}{ Cost Structure } & \multicolumn{2}{|c|}{$\begin{array}{l}\text { Revenue Stream } \\
\text { - } \text { Product sale } \\
\text { - IPLK costs } \\
\text { - Costs for house renovation and building lots } \\
\text { - Penalty costs } \\
\text { - KPR rejection costs }\end{array}$} \\
\hline
\end{tabular}

Description: : maintained : created : improved : reduced 
Customer Segments: In the improved business model, the company is expected to increase their attention towards the millennial market segment because this segment is a large market that needs to be managed in order to bring maximum profit. The enhancement of the millennial segment can be done with a variety of proposed strategies such as providing insights on the benefits of investment, providing special promo programs, and launching products with the latest technology like smart home and home care applications.

Value Proposition: In order to be more superior compared to its competitors, companies must make improvements and develop their products. If so far the company has offered the concept of housing in the CBD area, then in the business model of improvement the company is expected to have begun building the CBD area so that it can provide certainty to customers that what is offered is no longer just a concept. In addition, the presence of the CBD will greatly affect the value of land and buildings investment in the area so that it will add the value of the products produced by the company. Beside increasing product value, companies also need to create new values on the products that are being produced such as highlighting the concept of environmentally friendly buildings, as well as the application of smart home technology and home care applications. Moreover, the advantages of these products have not been maximally applied by competitors so the value of the products offered by the company will be more superior.

Channel: Direct marketing can be done more interactively through talk shows or seminars. To be more interesting, the talk show material presented should be made so that it is not monotonous about company products but contains general knowledge related to products such as investments in property or the benefits of green open space in residential areas. In addition, companies can increase the intensity of online marketing rather than offline marketing.

Customer Relationship: The relationships that the company have with their customers are currently focused on establishing relationships with potential customers. For this reason, in the improved business model, better relationships management with customers who have purchased the products is needed. Managing relationships with customers can be done by improving personal services to these customers.

Revenue Stream: With the increase in featured products and market expansion in the proposed strategy, the interest of potential customers will also increase which will increase the company's sales as well.

Key Activity: To carry out the recommended strategy, there will be an increase in activity, especially in terms of marketing, construction and after-sales. The enhancement of marketing activities are carried out through more interactive marketing programs, education for prospective customers and more partnerships to expand market reach. Meanwhile, the increase in construction activities is carried out by completing infrastructure development and providing additional value to the product. While after-sales activities also need to be improved to perfect previous activities, one of which is through improving personal services.

Key Resources: Increased resources are needed to apply new strategies for companies such as improving the quality of human resources, especially the quality of marketers in controlling products, gaining customers, and increasing technological resources because they are in correspondence with targeted segments such as millennial markets who are familiar with technological advancements. 
Key Partnership: Companies can increase partnerships by working with other Ciputra business units like malls and hotels to create more attractive promotional programs and invite customers to become sales agents by providing incentives.

Cost Structure: The strategies that are being implemented will increase several cost components such as product development costs and infrastructure development costs.

\section{CONCLUSION}

Conclusion. Based on the results of the identification of PT CNI business model mapped in $\mathrm{BMC}$, it is found that there are elements that have not been optimally developed by the company so it is necessary to develop more strategies to optimize those elements. There are several environmental factors that affect company sales, both internally and externally. Ten strategies that can be applied by PT CNI are produced based on the development of strategies carried out. These strategies are (1) providing edu-promotion to the public regarding the benefits of investment, (2) applying the concept of environmentally friendly buildings, (3) creating special millennial promotion programs, (4) creating products with smart home technology, (5) developing home care applications, (6) providing incentives for customers, (7) collaborating with other Ciputra business units, (8) to start building CBD areas, (9) recruiting experienced marketers, and (10) improving personal services for customers. From the results of these improvements it is found that almost all elements in BMC will be improved, such as elements of customer segments, channels, value propositions, revenue streams, key activities, and cost structures. In addition there is also a reduction in the elements of channels and the creation of new strategies for the elements of customer relationships, channels, value propositions and key partnerships.

Suggestion. Further research can be expanded by conducting time analysis, financing analysis and impact analysis in applying the results of this research strategy. This can be done so that more accurate analysis results can be obtained in implementing these strategies.

\section{REFERENCES}

Abiyyu, I., Najib, M., Asmara, A. (2020). Bancassurance Business Strategy in Life Insurance: a Case Study One of Joint Venture Company in Indonesia. Jurnal Dinamika Manajemen. 11(1): 102-114. DOI: 10.15294/jdm.v11i1.21868.

Amanulla, A.N., Faizah, A.A., Farah, N.H., Jamaludin I. (2015). Comparison of Business Model Canvas (BMC) Among the Three Consulting Companies. International Journal of Computer Science and Information Technology Research. 3(2): 462-471.

Amin, A.M., Baga, L.M., Tinaprilla, N. (2018). Strategi Perencanaan Model Bisnis Perusahaan Jasa Konsultan Arsitektur dan Jasa Konstraktor PT Architectaria Media Cipta. Jurnal Manajemen Pengembangan Industri Kecil Menengah. 13(1): 55-65. DOI: https://doi.org/10.29244/mikm.13.1.55-65.

Ariendi, G.T., Daryanto, A., dan Sanim, B. (2015). Strategi Peningkatan Daya Saing Bisnis Green Propery (Studi kasus: PT. Ciputra Indah di Pekanbaru). Jurnal Ekonomi dan Bisnis. 9(3): 153-163. 
[BI]. Bank Indonesia. (2020). Survei Harga Properti Residensial. Retrieved from: https://www.bi.go.id/id/publikasi/survei/harga-properti-primer/Default.aspx/3-32020.

Bobillo, A.M., Lopez-Iturriaga, F., Tejerina-Gaite., F. (2010). Firm Performance and International Diversification: The Internal and External Competitive Advantages. International Business Review. 19(6): 607-618. DOI: https://doi.org/10.1016/j.ibusrev.2010.03.006.

[BPS]. Badan Pusat Statistik Provinsi DKI Jakarta. (2020). Provinsi DKI Jakarta dalam Angka: DKI Jakarta Province in Figure 2020. Retrieved from: https://jakarta.bps.go.id/publication/2019/08/16/eea4f4b387c3024bb4a3a7fc/provins i-dki-jakarta-dalam-angka-2019.html/14-3-2020.

Capps, C.J., and Glissmeyer, M.D. (2012). Extending the competitive profile matrix using internal factor evaluation and external factor evaluation matrix concepts. Journal of Applied Business Research. 28(5):1059-62. DOI: 10.19030/jabr.v28i5.7245.

Chesbrough, H., and Rosenbloom, R.S. (2002). The Role of The Business Model in Capturing Value from Innovation: Evidence from Xerox Corporation's technology spin-off companies. Industrial and Corporate Change. 11(3): 529-555. DOI: $10.1093 / \mathrm{icc} / 11.3 .529$.

Casadesus-Masanell, R., and Ricart, J. E. (2010). From strategy to business models and onto tactics. Long range planning. 43(2): 195-215. DOI: https://doi.org/10.1016/j.lrp.2010.01.004.

Darmawan, H., Daryanto, A., Sukardi. (2015). Strategi Pengembangan PT XYZ Dalam Agribisnis Teh Hijau. Jurnal Manajemen. 19(1): 85-100. DOI: http://dx.doi.org/10.24912/jm.v19i1.107.

David, F. (2013). Strategic Management: Concept and Cases. London (UK): Pearson Education Limited.

Dudin, M.N., Katsuri, G.N., Fedorova, I.J., Dzusova, S.S., Namitulina, A.Z. (2015). The Innovation Model Canvas in System of Effective Budgeting. Journal Asian Social Science. 11(7):290-296. DOI: 10.5539/ass.v11n7p290.

Erdiono, D. (2009). Arsitektur Hijau: Arsitektur Ramah Lingkngan. Jurnal Ekoton. 9(1): 75-77.

Eskelinen, T., Rasanen, T., Santi, U., Happonen, A., Kajanus, M. (2017). Designing a Business Model for Environmental Monitoring Service Using Fast MCDS. Technology Innovation Management Review. 7(11): 36-47. DOI: 10.22215/timreview/1119.

Ferrel, O.C., and Harline, D. (2005). Marketing Strategy. South Western: Thomson Corporation.

Fielt, E. (2013). Conceptualising Business Models: Definitions, Frameworks and Classifications. Journal of Business Models. 1(1): 85-105. DOI: https://doi.org/10.5278/ojs.jbm.v1i1.706.

Gavrilova, T., Alsufyev, A., Yanson, A.S. (2014). Modern National of Business Model Visual Tren. Journal Foursight-Russia. 8(2): 56-70.

Ghezzi, A. (2014). The Dark Side of Business Models: Strategizing Through Bussiness Models Alone. Journal Strategic Direction. 30(6): 1-4. DOI: 10.1108/SD-03-20140036 . 
[KEMENPPPA]. Kementerian Pemberdayaan Perempuan dan Perlindungan Anak. (2018). Statistik Gender Tematik: Profil Generasi Milenial Indonesia. Retrieved from: https:/kemenpppa.go.id/lib/uploads/list/9acde-buku-profil-generasi-milenial.pdf/163-2020.

Kim, W.C., and Mauborgne, R. (2005). Blue Ocean Strategy: How to Create Uncontested Market Space and Make the Competition Irrelevant. US: Harvard Business School Publishing.

Maassen, M.A. (2018). Sustainable Business Models: An Imperative in the Strategic Management of Companies and Organizations. Management Dynamics in the Knowledge Economy. 6(2): 323-335. DOI: 10.25019/MDKE/6.2.09.

McGrath, R.G. (2010). Busines Models: A Discovery Driven Approach. Long Range Planning. 43(2): 247-261. DOI: https://doi.org/10.1016/j.lrp.2009.07.005.

Moser, H.C. (2006). How to SWOT Southeast Asia. Manufacturing Engineering. 136(1):120.

Osterwalder, A., and Pigneur, Y. (2012). Business Model Generation: A Handbook for Visionaries, Game Changersand Challengers, John Wiley \& Sons. Jakarta: PT Alex Media Komputindo.

Pearce, J. A., and Robinson, J. R. B. (2011). Formulation, Implementation and Control of Competitive Strategy. New York (US): McGraw Hill.

Shafiq, M., Tasmin, R., Takala, J., Qureshi, M.I., and Rashid, M. (2017). Relationship of Blue Ocean Strategy and Innovation Performance, an Empirical Study. City University Research Journal. 74-87.

Rainaldo, M., Wibawa, B.M., Rahmawati, Y. (2017). Analisis Business Model Canvas Pada Operator Jasa Online Ride-Sharing (Studi kasus Uber di Indonesia). Jurnal Sains dan Seni ITS. 6 (2): 235-239. DOI: 10.12962/j23373520.v6i2.25277.

Tokarski, A., Tokarski, M., and Wojcik, J. (2017). The Possibility of Using the Business Model Canvas in the Establishment of an Operator's Business Plan. Torun Business Review. 16(4): 17-31. DOI: 10.19197/tbr.v16i4.117.

Trkman, P., Budler, M., Groznik, A. (2015). A Business Model Approach to Supply Chain Management. Supply Chain Management: An International Journal. 20(6): 587-602. DOI: 10.1108/SCM-06-2015-0219.

Turban, E. (2011). Decision Support System and Intelligent Systems. Yogyakarta: Andi. Wheelen, T.L., and Hunger, J.D. (2012). Strategic Management and Business Policy: Toward Global Sustainability. New Jersey (US): Prentice Hall International. 